\title{
First Cytogenetic Description of the Species Rhamdella microcephala (Pisces, Hepapteridae)
}

\author{
Yris Maria Fonseca ${ }^{1}$, Claudio Oliveira ${ }^{2}$, Fausto Foresti ${ }^{2}$ and \\ Edson Luis Maistro ${ }^{1, *}$ \\ ${ }^{1}$ Instituto de Farmácia e Nutrição, UNIFENAS, 37130-000, Alfenas, MG, Brazil \\ ${ }^{2}$ Departamento de Morfologia, Instituto de Biociências, UNESP, \\ Câmpus de Botucatu, 18618-000, Botucatu, SP, Brazil
}

Received December 9, 2002; accepted December 12, 2002

\begin{abstract}
Summary Cytogenetic studies were carried out on Rhamdella microcephala collected from the headwaters of the Machado river, a tributary of the Sapucaí river, Minas Gerais, Brazil. Sixteen specimens exhibited $2 n=56$ chromosomes, with 18 metacentrics, 30 submetacentrics and 8 subtelocentric-acrocentrics $(\mathrm{FN}=84)$. The nucleolar organizing regions $(\mathrm{NORs})$ were identified in the interstitial position on the long arm of a submetacentric pair (pair 12). Chromomycin $\mathrm{A}_{3}$ staining evidenced only the NOR-bearing segments. Positive C-band segments were identified in a pericentromeric position in most of the chromosomes and the NOR-bearing segments were also C-band positive. Some aspects related to the chromosomal characteristics of Rhamdella microcephala are discussed.
\end{abstract}

Key words Rhamdella microcephala, Cytogenetics, C-band, NOR, Hepapteridae.

According to Nelson (1994), the order Siluriformes is a group of fish with about 2400 species distributed among 34 families and 412 genera. Although several taxonomic revisions of Siluriformes families have appeared, the systematics of the groups that constitute this order is still unresolved (de Pinna 1998).

The cytogenetic data available to the Hepapteridae family are scarce but members of this groups exhibit an extensive karyotypic variability (Oliveira and Gosztonyi 2000). For the genus Rhamdella, only 1 species, Rhamdella sp. from Bahia state, Brazil, was cytogenetically studied (Souza et al. 1994) and the results obtained showed that it had $2 n=56$ chromosomes (26M$\mathrm{SM}+30 \mathrm{ST}-\mathrm{A})$. The objective of the present paper is to describe for the first time the karyotype, the number and location of the nucleolus organizer regions, the pattern of distribution of C-band positive segments, and the pattern of chromomycin $\mathrm{A}_{3}\left(\mathrm{CMA}_{3}\right)$ staining of Rhamdella microcephala. The data were compared with others available for the family Hepapteridae in order to achieve a better understanding of the chromosomal evolution of this family.

\section{Materials and methods}

A cytogenetic survey was performed on 16 specimens (not sexed) of Rhamdella microcephala collected from the Machado river, a tributary of the Sapucaí river which passes through the town of São João da Mata, state of Minas Gerais, Brazil (S 22 $04.471^{\prime}-\mathrm{W} 46^{\circ} 02.810^{\prime}$ ). The fishes were identified and are deposited in the fish collection of the Laboratório de Pesquisas em Genética, UNIFENAS, Brazil.

Mitotic cells were obtained from gill and kidney tissues by the technique described by Foresti et al. (1993). Chromosome morphology was determined on the basis of arm ratios as proposed by Levan et al. (1964) and the chromosomes were classified as metacentrics (M), submetacentrics

\footnotetext{
* Corresponding author, e-mail: maistroedson@yahoo.com.br
} 
(SM), subtelocentrics (ST) and acrocentrics (A). The fundamental number (FN) was determined considering $\mathrm{M}$ and SM chromosomes with 2 arms and ST and A chromosomes with 1 arm. C-banding was performed by the method of Sumner (1972) and silver staining of nucleolus organizer regions (NORs) by the method of Howell and Black (1980). Chromomycin $\mathrm{A}_{3}$ staining was performed by the method of Schweizer (1980).

\section{Results and discussion}

The diploid number found in $R$. microcephala was $2 n=56(18 \mathrm{M}+30 \mathrm{SM}+8 \mathrm{ST}-\mathrm{A})$ with $\mathrm{FN}=84$ (Fig. 1). Only 1 species of this genus, Rhamdella sp. from Itaetê town, Bahia, Brazil, has been cytogenetically studied and presented $2 n=56$ chromosomes $(26 \mathrm{M}-\mathrm{SM}+30 \mathrm{ST}-\mathrm{A})$ and $\mathrm{FN}=82$ (Souza et al. 1994). A diploid number of $2 n=56$ is the most frequent among Hepapteridae species and may be the ancestor diploid number for the order Siluriformes (Oliveira and Gosztonyi 2000).

In Rhamdella microcephala the NORs were found in an interstitial position on the long arm of a large submetacentric pair (pair 12) and exhibited a large size heteromorphism in some individuals (Fig. 3a). This heteromorphism has been commonly described among Neotropical fishes (AlmeidaToledo and Foresti 1985). Considering that the presence of only 1 NOR-bearing chromosome pair with terminal NORs is the most common feature found among teleost fishes (Almeida-Toledo and Foresti 1985, Klinkhardt 1998), the occurrence of the NORs located in an interstitial position on the chromosomes of $R$. microcephala and of some other species of Siluriformes could be a derived trait for the species that have them (Oliveira and Gosztonyi 2000).

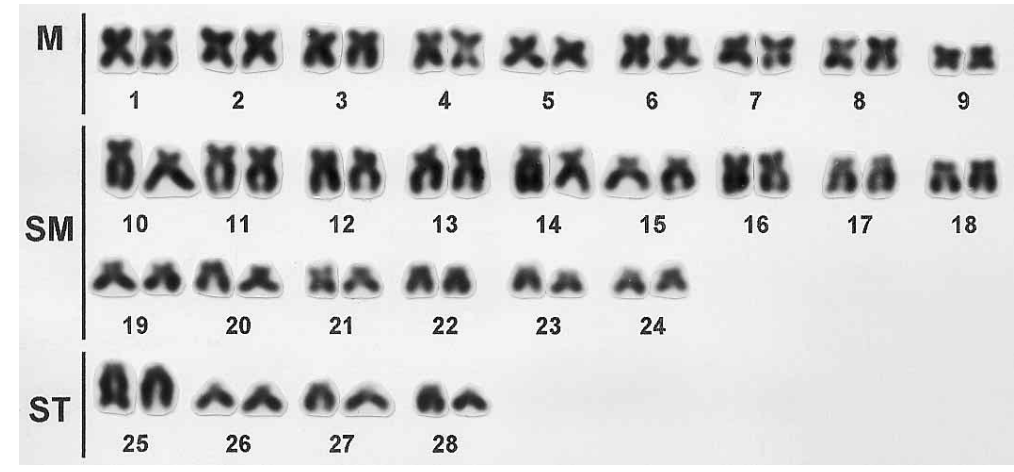

Fig. 1. Karyotype of Rhamdella microcephala collected from the Machado river headwaters after Giemsa staining.

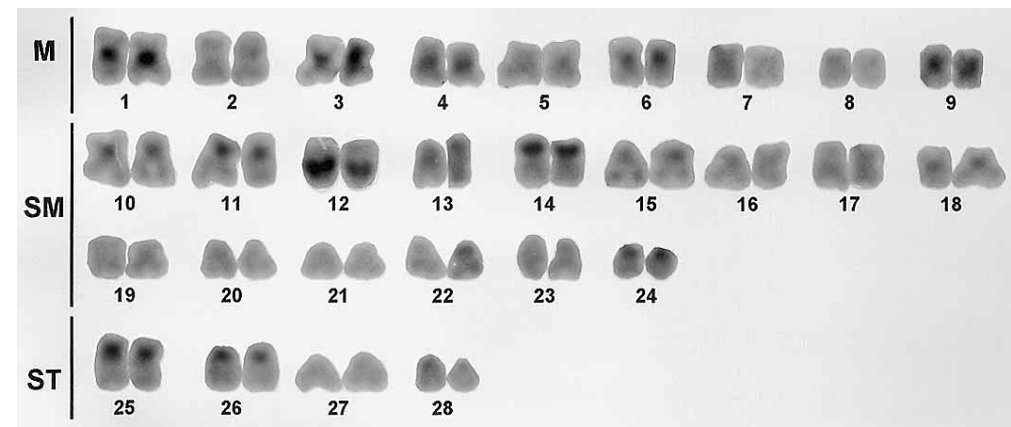

Fig. 2. Karyotype of Rhamdella microcephala collected from the Machado river headwaters after C-banding. 


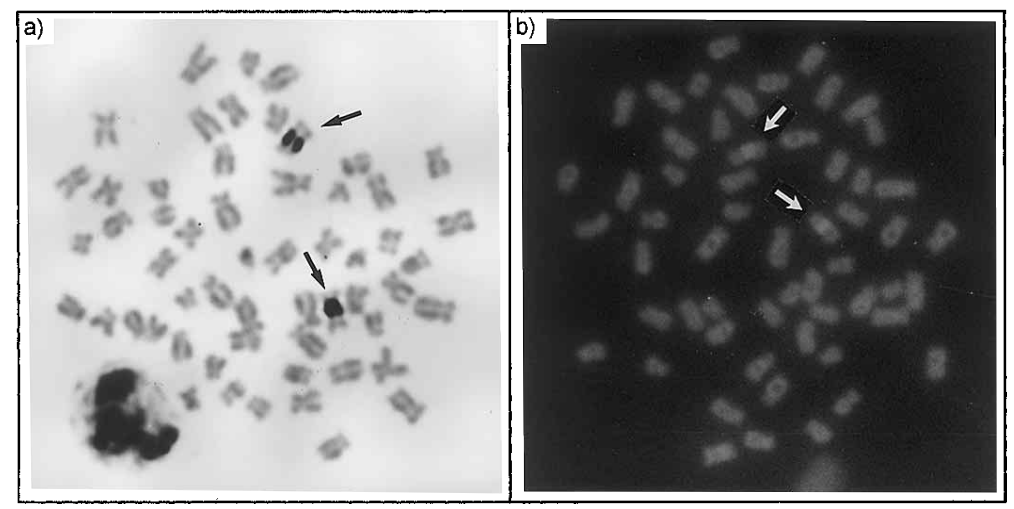

Fig. 3. Metaphase chromosomes of Rhamdella microcephala. a) Ag-NOR-bearing chromosomes (arrows) and b) $\mathrm{CMA}_{3}$ staining (arrows).

Chromomycin $\mathrm{A}_{3}$ is considered to be a GC-specific fluorochrome (Schweizer 1980) that yields fluorescent bands at NOR sites of the chromosomes of lower vertebrates, including fish (Amemiya and Gold 1986, Galetti-Jr. and Rasch 1993, Maistro et al. 2000, 2001, among others). In R. microcephala only the NOR-bearing chromosome pair exhibited a bright signal after $\mathrm{CMA}_{3}$ staining (Fig. $3 b$ ), indicating that the NOR region may contain NOR-associated heterochromatin rich in GC base pairs. On the other hand, these data suggest that the other C-band-positive segments found in this species are not rich in GC base pairs. This characteristic has been commonly found in several fish species (Amemiya and Gold 1986, Maistro et al. 2000, Swarça et al. 2001, among others).

In $R$. microcephala, C-banding showed the occurrence of heterochromatin in the pericentromeric region of most chromosomes, more clearly visible on pairs 1, 3, 4, 6, 9, 11, 24, 25 and 26 (Fig. 2). The NOR segment and the entire short arm of pair 14 was also found to be C-band positive. Although a small amount of heterochromatin has been commonly described among Hepapteridae species and many other teleost species (Gold et al. 1990), this was not observed in R. microcephala.

The data obtained in the present study indicate that, besides the conserved diploid number $(2 n=56)$, rearrangements in the karyotypes, such as changes in the number and position of the NORs and in the among of heterochromatin, might be important mechanisms of chromosome diversification in some Hepapteridae species. The occurrence and fixation of these rearrangements might be facilitated by fact that some species of $R$. microcephala live in the headwaters of small streams, rivers in mountain regions or small rivers in caverns isolated from other populations. The association of rapid changes in karyotypic features and population structure has been suggested for several fish species like Astyanax scabripinnis (Moreira-Filho and Bertollo 1991, Maistro et al. 1998) and the genus Trichomycterus (Torres et al. 1998).

\section{Acknowledgements}

The authors are grateful to Dr. Flávio A. Bockmann for identifying the specimens. Funds supporting this study were provided by CNPq, FAPEMIG and UNIFENAS.

\section{References}

Almeida-Toledo, L. F. and Foresti, F. 1985. As regiões organizadoras do nucléolo em perixes. Cien. Cult. 37: 448-453.

Amemiya, C. T. and Gold, J. R. 1986. Chromomycin $\mathrm{A}_{3}$ stains nucleolus organizer regions of fish chromosomes. Copéia 1: $226-231$. 
de Pinna, M. C. C. 1998. Phylogenetic Relationships of Neotropical Siluriformes: Historical Overview and Synthesis of Hypotesis. In Malabarba, L. R., Reis, R. E., Vari, R. P., Lecena, Z. M. S. and Lucena, C. A. S. (eds.). Philogeny and Classification of Neotropical Fishes, EDIPUCRS, Porto Alegre. pp. 279-330.

Foresti, F., Oliveira, C. and Almeida-Toledo, L. F. 1993. A method for chromosome preparations from large fish specimens using in vitro short-term treatment with colchicine. Experientia 49: 810-813.

Galetti-Jr, P. M. and Rasch, E. M. 1993. Chromosome studies in Poecilia latipunctata with NOR polymorphism as shown by silver nitrate and chromomycin $\mathrm{A}_{3}$ (Teleostei: Poeciliidae). Ichthyol. Explor. Freshwaters 4: 269-277.

Gold, J. R., Li, Y. C., Shipley, N. S. and Powers, P. K. 1990. Improved methods for working with fish chromosomes with a review of metaphase chromosome banding. J. Fish Biol. 37: 563-575.

Howell, W. M. and Black, D. A. 1980. Controlled silver-staining of nucleolus organizer regions with a protective colloidal developer: a 1-step method. Experientia 36: 1014-1015.

Klinkhardt, M. 1998. Some aspects of karyoevolution in fishes. An. Res. Devel. 47: 7-36.

Levan, A., Fredga, K. and Sandberg, A. A. 1964. Nomenclature for centromeric position on chromosomes. Hereditas 52: 201-220.

Maistro, E. L., Oliveira, C. and Foresti, F. 1998. Comparative cytogenetic and morphological analysis of Astyanax scabripinnis paranae (Pisces, Characidae, Tetragonopterinae). Gen. Mol. Biol. 21: 201-206.

- , - and - 2000. Cytogenetic analysis of A- and B-chromosomes of Prochilodus lineatus (Teleostei, Prochilodontidae) using different enzyme banding and staining methods. Genetica 108: 119-125.

- - - and - 2001. Cytogenetic characterization of a supernumerary chromosome segment and of B-chromosomes in Astyanax scabripinnis (Teleostei, Characidae). Genetica 110: 177-183.

Moreira-Filho, O. and Bertollo, L. A. C. 1991. Astyanax scabripinnis (Pisces, Characidae): a species complex. Braz. J. Genet. 14: 331-357.

Nelson, S. J. 1994. Fishes of the World. John Wiley \& Sons.

Oliveira, C. and Gosztonyi, A. E. 2000. A cytogenetic study of Diplomystes mesembrinus (Teleostei, Siluriformes, Diplomystidae) with a discussion of chromosome evolution in siluriforms. Caryologia 53: 31-37.

Schweizer, D. 1980. Simultaneous fluorescent staining of R bands and specific heterochromatic regions (DA-DAPI bands) in human chromosomes. Cytogenet. Cell Genet. 27: 190-193.

Souza, I. L., Moreira-Filho, O. and Castro, R. M. C. 1994. Informações Citogenéticas Preliminares de Uma Nova Espécie de Pimelodidae Cego de Cavernas (Itaetê, BA). Resumos do V Simp. Citogen. Evol. Aplic. Peixes Neotrop. pp. 18.

Sumner, A. T. 1972. A simple technique for demonstrating centromeric heterocromatin. Expl. Cell Res. 75: 304-306.

Swarça, A. C., Giuliano-Caetano, L. and Dias, A. L. 2001. Analyses of nucleolus organizer regions and heterochromatin of Pimelodus maculatus (Pisces, Pimelodidae). Genetica 110: 97-100.

Torres, R. A., Foresti, F. and Oliveira, C. 1998. Comparative cytogenetic studies in allopatric populations of Trichomycterus paolence Eigenmann, 1918 from Southeastern Brazil (Siluriformes, Trichomycteridae). Cytologia 63: 107-114. 